Petr P. Kozorezenko

Ph.D. in Art History,

Honored Artist of the Russian Federation

Professor,

Head of the Art of Graphics Department

Stroganov Moscow State Academy of Industrial and Applied Arts

e-mail: 7245631@mail.ru

ORCID 0000-0001-8949-6249

DOI: 10.36340/2071-6818-2021-17-2-79-100

\title{
THE IMAGE OF THE ICON IN THE WORKS OF THE SEVERE STYLE ARTISTS
}

Summary: The appeal to the artistic traditions of different eras - peculiar perception of the techniques of post-impressionism, the heritage of the Russian avantgarde, the search of the Soviet painters of the 1920s-1930s, as well as the art of Proto-Renaissance and Ancient Rus, became an important impetus to the creativity of the severe style artists. With artistic experiments and active use of various graphic lines, they skillfully combined the experience of ancient Russian art in their works; they used the icon and fresco painting traditions and primitivism painting together with modern patterns.

Ancient Russian art and its primary embodiment the icon, became the latent, not obvious dominant of the art of the severe style masters. The works of outstanding icon painters of the past (Theophanes the Greek, Andrei Rublev, Dionisius), who embodied a new, sublime understanding of man's spiritual beauty and moral strength in their works, were the pinnacle of skill for representatives of this art movement.

In Russian icons, the severe style artists were attracted by local colours, simplified composition and forms, and a "frozen" plot. They were even more attracted by their colour saturation, joyful power or harshness of pure colours. However, the connection with icon painting is not

The cardinal metamorphoses of the spiritual and moral life of the people during the Eastern Front of World War II marked the beginning of a new stage in artists' artistic practice, sharpened their susceptibility to hidden elements and trends of reality.

The search led to the approval of a new hero a contemporary creator, self-collected, demonstrating the firmness of moral principles, ready for work and struggle. Self value of a living person, freed only in the technical aspects of painting. In the works of the severe style artists, as in the icon, emotional stress is focused on the inner life and is not expressed by external exaltation.

The appeal to icon painting was not accidental: the artists felt the sad disappearance of the connection between generations, the tragic breakdown of age-old foundations, godlessness and... desperate longing for some other, unearthly Truth. All the complexity of the internal self-determination of the generation of the 1960s-1970s is seen in these voices of the era. The severe style representatives tried to reveal the theme of Light and Meaning, as much as possible in the conditions of Soviet times. Their paintings showed the truth of this search.

The severe style, a phenomenon that was so categorically assigned the status of something episodic, even fleeting, turned out to be compatible in different versions with philosophical and religious postulates that have been relevant at all times, with the national idea, with an attraction to eternity.

Keywords: severe style, Russian icon, religious plot, ascetic faces, moral strength, truth of life, Popkov, Nikonov, Korzhev.

from ideological husks, led artists to develop the theme of a person and his or her place in the modern world. Young masters wanted to show the hero of everyday work in close-up in typical circumstances of their time.

In painting, a new specific way of revealing the hero's inner world was indicated in the concealment of spiritual energy and potential in a laconic form. The essence was conveyed through the search for 
the relationship between the external appearance and the internal state of a person. A new interpretation of space and time appeared; the works began to differ in the breadth of ideological generalisations. The common goal, which brought together a large group of artists, gave rise to a commonality of aesthetic principles and formal techniques and was later conventionally called the severe style.

The artists felt the deterioration of the "old" technical means and compositional systems, denying the passivity of the "ceremonial" works of art. Therefore, they turned to the search for new artistic techniques that could arouse interest and involve the viewer in a fascinating process of searching for the spirit of the times and affirmation of the renewed person, trying to push to empathise with the content of their work. In the works of the future severe style artists - P. Ossovsky's At the Crossing, G. Korzhev's In the Days of War and V. Stozharov's Off For the Wood, which were presented at the first youth exhibition, art critics and viewers felt a change in the intonation structure in the perception of the surrounding reality - restraint, concentration, laconicism, authenticity.

A unique life experience, intolerance of lies, a creative principle, a meaningful approach to creativity, a strong civic position and fearlessness were the leading qualities of the generation. The artists did not break ties with the previous heritage. By isolating all the most valuable, ideologically clean, they put together new art from these components, giving their moral assessment of modernity and recent history. They wanted to have their say and be heard; thus, everyone fought for their creativity to the end.

In an attempt to grasp the nerve of the time, the severe style artists went to "document" reality in the corners of the country with harsh nature. The search for a real person, working under challenging conditions, spending every day in the fight against the elements, began to dictate its new pictorial language: a disregard for the beauty of nature, conventionality and graphicality of its image, restrained colour, monumental-poster laconic forms, a special type of heroes and internal emotional saturation in paintings (energy, restraint, audacity, overcoming, drama), the epic perception of the scenes presented by an artist.

Artists of the severe style sought to oppose their work to the semi-official pathos of the poster and the official imperial side of socialist realism. Already in the context of their early work, parameters of the severe style such as the depiction of unadorned reality, a departure from the detailed literary narration, the desire for a psychological interpretation of images, the metaphor of the artistic language, expanding the semantic boundaries of the work, were gradually developed.

This disarming unpretentiousness acted stronger than the boring cliché images of a "creative person". Moreover, it had its life authenticity since an artist's existence consisted of such ordinary situations, quite everyday, but at the same time filled with a secret inner life, miraculously resolved by works of art.

The theme of everyday work, the poeticisation of a person's daily work were the focus of the severe style artists. The most prosaic and mundane became the subject of monumentalisation and proud exaltation. Their characters were people of brutal professions - builders, geologists, repairmen, raftsmen, polar explorers. They had individual portrait features and formed a collective image of a courageous hero. Everything in these characters spoke of their difficult life, perseverance, spiritual and physical strength.

The new style demonstrated the Protestant type of hero - a responsible adult, with his or her own experience, personal faith and generally developed internal motivation (and therefore, without the need of external ideological stimulation from the party), although acting within the framework of a general transformation project. The artists were able to look around for a while, understand the time and themselves, escape from the insulting falseness of Soviet ideological and educational rituals, from the capital's showcases of communist prosperity into the inner world of the common man.

The artists were more absorbed in reflecting the inner, spiritual work of the characters than in describing the reality around them. Most of all, in the interpretation of the external appearance of the heroes, artists paid attention to the faces and hands of the characters since it is they and their interaction that manifest the inner state of a person. Although sometimes not the faces of individual people but the spiritualised face of a whole generation was portrayed in the works of the severe style artists.

In accordance with their understanding of the world and the general impression of emotional tension, the severe style artists chose artistic means as well. In search of the "truth of life", artists P. Nikonov, V. Popkov, G. Korzhev, brothers A. and P. Smolin, 
P. Ossovsky and others turned to a restrained, conventional, generalised form, rejecting any descriptiveness. Often, artists worked with large planes, used rigid plastic formulas, enlarged and flattened the image. The works are characterised by such artistic features as laconism, rhythmic, but balanced and monumentalized, predominantly frontally deployed composition with sharp linear rhythms, clear outlines of contours, constructive moulding of form, expressiveness, colouristic restraint with lapidary colour spots. Like the whole atmosphere of their paintings, colour emphasised the severity of the theme and images of the heroes, accentuated asceticism and spiritual saturation, depth. The paintings are dominated by shades of black, brown, earthy colours and other minor tones. Close-ups, provoking gazing at the heroes, were used. These paintings are very close to the pictorial traditions of Old Russian icons and early Russian "personal" portraits of the $17^{\text {th }}$ century.

The appeal to the artistic traditions of different eras - their peculiar perception of the techniques of post-impressionism, the heritage of the Russian avant-garde, the search of the Soviet painters of the 1920s-1930s, as well as the art of Proto-Renaissance and Ancient Rus, was an essential impetus to the creativity of the severe style masters. With artistic experiments and active use of various graphic lines, they skillfully combined the experience of ancient Russian art in their works; they used the icon and fresco painting traditions, primitivism painting together with modern patterns.

The artists were inspired by masterpieces of the past centuries. They seemed to be in a constant internal dialogue with the masters, whose heritage had been a source of fruitful ideas in Russian pictorial culture for centuries and could not be destroyed in several decades.

Studying the work of masters of the past significantly expanded the stylistic and thematic boundaries of the work of Soviet artists. Art criticism studies, "rehabilitating" several artists, whose work had long been considered not worthy of attention, played a significant role in the reassessment of the past and the present.

The programmatic works of the severe style, Rafters by Nikolai Andronov and Geologists by Pavel Nikonov, demonstrate various sources. Pyotr Konchalovsky's colour effects are combined with the motifs of Alexander Deineka in Plotogons, whereas Pavel Kuznetsov's tradition with a projection on the icon-painting style of Dionisius, which in the eyes of Soviet ideologists of the early 1960s looked like absolute revolt, is actualised in Geologists. The very fact that the severe style artists turned to previously forbidden traditions was already perceived as a radical, innovative gesture by contemporaries, although certain exhaustion and "weariness" of the thematic picture was already felt in the painting of the 1960s.

In the works of Viktor Popkov, Viktor Ivanov, Dmitry Zhilinsky, Tatyana Nazarenko, it is evident that they appeal not only to their neighbours but also to distant traditions - Old Russian icon painting, the art of the early Renaissance, primitive works of the $18^{\text {th }}$ century.

It was ancient Russian art and its primary embodiment, the icon, that became a hidden, not apparent dominant and a beacon to which the masters of the severe style turned. Iconography for centuries served as the starting point of Russian art and an invisible thread connecting the masters of painting with their different styles, creative aspirations... It served as an involuntary model, a canon, sometimes intuitive, for different generations of Russian painters. The pinnacle of skill for many Soviet artists was the activity of outstanding icon painters of the past (Theophanes the Greek, Andrei Rublev, Dionisius), who embodied a new, sublime understanding of the spiritual beauty and moral strength of man in their works.

The severe style artists were attracted to Russian icons by local colours, a simplified composition and forms, a "frozen" plot... They were even more attracted by their colour saturation, joyful power or harshness of pure colours.

For example, early examples of Rublev icon painting correspond to the general rules followed by the artists of the severe style. In the Orthodox icons of the $14^{\text {th }}-15^{\text {th }}$ centuries, it was customary to depict severe and ascetic faces with characteristic Byzantine features: large eyes, a high forehead, a straight nose and thin lips. The craftsmen mainly used restrained, dark colours: dark red, brown, ochre yellow.

The icon painter and restorer of the early $20^{\text {th }}$ century, Vasily Guryanov, described the early works of Rublev as follows: "the faces are painted in thin layers, observing the sequence in the transition from illuminated to unlit places; they look greenish in the shadows and are modelled with brown ("dark") ochre without marks, that is without hits in the brightest places to indicate highlights with white paint; in accordance with the faces, the figures are also lightly modelled, and the outline is indicated only by a thin line". 
The connection with icon painting was not only in the technical aspects of painting. In the works of the severe style artist, as in the icon, emotional stress is focused on the inner life and is not expressed by external exaltation. Instead, this painting is about the amazing balance of all lines and details, about the internal balance, about the precisely adjusted centre line on masterfully painted images... In this sense, the artists of the severe style were heirs to the traditions of the Russian school of painting; they depicted severe and ascetic faces.

Obviously, the involuntary appeal to icon painting was not accidental: the artists felt the sad disappearance of the connection between generations, the tragic breakdown of age-old foundations, godlessness and... desperate longing for some other, alien Truth. All the complexity of the internal self-determination of the generation of the 1960s-1970s is seen in these voices of the era.

None of the artists was a church person, and anyway, that was impossible in Soviet times. However, there was a spiritual, "root" connection with parents who grew up in faith with artistic traditions. This Christian subtext is more likely to shine through than it is clearly pronounced, which was evident in the era of totalitarian atheism. It seems that a constant desire to "bite into life, learn, comprehend the basic laws of our being" (V. Popkov) was main here.

These were not directly religious subjects; however, in these themes, the artists touched upon something inevitably important, existing in the inner life of every person. In their main works, the artists tried to intuitively break through the border of a particular spiritual tightness of their generation, about which V. Vysotsky figuratively wrote: "And ice from below, and from above...".

Representatives of the severe style tried to reveal the theme of Light and Meaning as much as possible in the conditions of Soviet times. The truth of this search was seen in their works. They understood in a unique way, intuitively felt the invisible connection of times, the continuity of generations and traditions.

The tradition of Russian religious art was interrupted after 1917. It is interesting to note that at the same time, icons, as part of the cultural heritage, became the object of scientific research. At the same time, the atheistic policy of the state, imposing a ban on religious themes and plots, did not prevent artists who created the image of a new person in their works from resorting to formal borrowings coming from icon painting: light streaming onto the depicted model from everywhere and seemingly emanating from it (transcendental light), standing pose, front view.

Although the tradition of icon painting in the Soviet period, it would seem, was interrupted, the severe style artists were gradually looking for a way out of their creative ideas and conversation in a similar pictorial language, continuing the centuries-old traditions of icon painting, perhaps unconsciously, temporarily replacing icon painting and interpreting it in accordance with the life during Soviet times.

The severe style artists' works, related to religious issues, are a special part of their work. They became a continuation of the artists' reflections on important moral and philosophical problems, as well as an acute inner need to turn to the sources - the canons of pictorial skill, which icon painting was considered to be at all times.

Addressing this topic seems unexpected only at first glance: on the one hand, it was a way to express your protest and rejection of the existing ideology and order. On the other hand, artists were attracted by the monumental paintings of churches, the purity and clarity of the colour palette of the icon painters of the $15^{\text {th }}-16^{\text {th }}$ centuries. They also drew their inspiration from the hagiographic icons of the $17^{\text {th }}$ century, their figurative structure and their strive for allegory. Appearing in a veiled form in landscape and genre paintings, this theme was formed and manifested itself in the artists' village series and became a continuation of their reflections on significant moral and philosophical problems of the time.

Its perception and interpretation are individually embodied in the art of each master. However, at the same time, there are also common features that unite the artists, making it possible to judge how the religious theme is revealed in the work of the severe style artists. The inclusion of signs or symbols associated with religious art, which are the source of additional, "encrypted" meaning, in the composition is one of the ways or means of revealing religious issues. The work becomes ambiguous; its ideas do not lie on the surface but are hidden in the artistic weaving of the painting. "For me, as well as for many artists of my generation," noted Viktor Ivanov, "it is characteristic that the artist's 'reflections' are not shown in the finished form in the painting. They are as if taken out of the painting and the viewer sees them."

The emergence of this theme in the works of the severe style representatives stems to some extent 
from the laws of ordinary mankind: at a specific moment in life, a person begins to think about eternal, enduring values. The result of a complex inner work the achievement of a certain stage of life, a new level of self-awareness of artists, led to the fact that questions about the meaning and essence of being became a cornerstone in their work. It is symptomatic that each of them was looking for their world of sacred images far from the capital: Nikolai Andronov worked in Ferapontovo, Viktor Ivanov - in his ancestral village in the Ryazan region, Viktor Popkov travelled in the Russian North, for Pavel Nikonov the Aleksino village in the Tver region became a creative laboratory for a long time, and Pyotr Ossovsky connected his creative work with the Pskov land.

Isolation from the hustle and bustle of a modern city, solitude, immersion in oneself - this is the way of life of a hermit engaged in a spiritual search, which, among other things, led the masters to think and experience religiously.

The most substantial perception and creative transformation of icon painting in its modern form manifested itself, perhaps, in Viktor Popkov's work.

There was a deep connection with ancient Russian icon painting in the artist's work, with the images created by Dionisius and Rublev. Many famous paintings by Popkov were created under the direct influence of the Russian icon painting tradition, which can be read about in his diaries. The artist's strongest impression of Russian art was precisely from the icon, from the works of Andrei Rublev.

Popkov even made one of his first self-portraits in the icon-painting style. In 1959, the artist had a trip to Pereslavl-Zalessky to a tvorcheskaya dacha, a special country house to live and create art. A. Tutunov recalled that the first work that Viktor Popkov showed him was a self-portrait: it was painted on cardboard lined into squares, the artist himself was depicted in the centre, and the impressions of Pereslavl were on the sides, like images, kleima, around the centrepiece in the icons.

In 1964, the artist specially travelled to the ancient Ferapontov monastery to make sketches from the frescoes of Dionisius. The artist liked their smooth flowing lines, soft combinations of light, slightly whitened, tones and a calm, as if melodious rhythm. It was then that Popkov began to paint a lot in the tempera painting technique.

Popkov liked the techniques dating back to the Russian icon-painting tradition and later used them more than once in his work. Echoes of the experi- ence at Ferapontov monastery are felt, for example, in the lightened palette of the Brigade: in the image of an exceptionally high, icon-like horizon, in a calm circular rhythm that creates a feeling of unity and harmony, in a departure from spatial depth, in features that make this canvas akin to the works of D. Zhilinsky, whose work Viktor Popkov treated with special attention at that time.

Popkov, like the great masters of past centuries, was often inspired by the works of other artists. It was never a direct borrowing but always a reinterpretation, in which there was more from Popkov's own creative individuality than from the original source. Another obvious analogy is the works of Palekh masters, which in turn also go back to icon painting: it was at that time that Popkov really considered and fell in love with the refined decorative sophistication of Palekh lacquer miniatures.

Viktor Popkov, who rather quickly dealt with the problems of the severe style and went deeper in his works, which were not limited to one art movement or another, is considered a classic, the best representative of the severe style artists mainly owing to the painting Builders of the Bratsk Hydroelectric

\section{Power Station.}

According to V. Barvenko, who arrived with Popkov in Bratsk, he was literally obsessed with the images of workers, drawing sketches from morning to evening. Aiming at creating a truly monumental work, he began to work even harder than usual. The idea to use a dark, night background in the artwork arose immediately, so the sketches for the painting were made at night. According to the artist himself, the idea of the painting was based on the desire "to make everyone as in icons, silhouettes on a black background". That is why monumental, "icon" figures of the workers appeared in the painting.

Another remarkable work by Popkov was done similarly - The Brigade is Resting (1965), which received recognition in Paris. Its characters do not function but stay in the space of the painting, immersed in their leisurely activities - reading, playing chess. Here, expressive techniques are even more refined than in the previous case: there is no perspective (instead, the foreground figures are placed in the lower part of the composition, and the more distant ones - in the upper part), and the mowed field on which the workers are lying is likened to a conditional planar golden background, giving this painting a similarity, not accidental, with an icon. 
At that time, a discussion of the painting The Brigade is Resting was published in one of the issues of the Tvorchestvo magazine, following the results of a professional round table: some artists spoke unkindly, many simply misunderstood this work. However, now, half a century later, it is evident that Popkov's findings were not only of artistic interest but also restored the possibility of a dialogue with the ancient Russian tradition, which seemed lost entirely until recently. Moreover, it was not a matter of borrowing individual motifs (at that time, quite modern themes prevailed in Popkov's art), but an attempt to comprehend the artistic language of icon painting - the structure of the visual field, colour patterns, etc.

A series of Mezen Widows by Popkov is permeated with special iconography. In the centre of the Widows, a tall, thin woman is depicted capturing the entire figure; her mournful face with deep wrinkles resembles an icon face or the face of an ancient wooden statue. It is turned to the viewer, but the woman restrained in emotions and full of sadness is immersed in her thoughts and memories. It seems as if the heroine of the painting has stepped down from the icon board, resurrecting in her memory the ancient icon-painting images of the holy martyrs. This is the most striking figure of all, austere and majestic; like a column, she holds the whole painting on her. Intuitively, almost guessing, Popkov approached the theme of Christian humble acceptance and bearing of the cross.

In Popkov's still life with a grey patchwork quilt, the appearance of an icon is noteworthy. On the one hand, it seemingly symbolises a connection with traditions, and on the other, it is painted unexpectedly unusually. Looking at it, you realise that you cannot recognize the plot depicted, that iconography of this kind does not exist and that it is obviously entirely invented by the artist, perhaps as a hint of the need for an eternal search in art.

In Popkov's painting Mother and Son, the artist painted himself sick, lying in bed under a large blanket, and portrayed his mother standing nearby and reading the Bible. The work is filled with warmth and comfort that the artist felt when he came to his mother. Stepanida was very devout; she worked for many years as a bell ringer in a church - it is with a prayer that she heals her son, running her finger along the lines in the Bible and addressing both her son and the icon of the Mother of God in the red corner. Viktor was never a devoutly religious per- son; however, he always treated believers with respect. The motif of motherhood is present in the painting in two ways - in the images of the mother and son and in the icon of the Mother of God with Jesus Christ. It is in common with the eternal theme of the Mother of God and the Child - the theme of sacrificial motherly love and prayer for her son, who is destined to carry his cross.

Surprisingly, it was in Germany that he conceived the idea of the painting In the Cathedral, depicting the interior decoration of a Russian church as if a short stay abroad stirred up nostalgia for something native, Russian. ...We see tourists raising their heads to the frescoes: elongated, almost ethereal (not in detail) figures of people look like frescoes practically erased by time and look less real than the shadows of images preserved on the walls of the cathedral - an exact metaphor for the ephemerality of human existence, momentary and transient, in contrast to the centuries-old frescoes. For this painting, Popkov made many pencils and pictorial sketches from Old Russian murals.

The painting I am 40 Years Old (1972), painted probably under the influence of Russian icon painting tradition, stands apart in the master's work. Looking at the image created by the artist, one can feel that the fortieth anniversary became an important milestone for the artist, an occasion to comprehend his own life and what he managed to do by that time. An angel is in the centre of the painting. It is a disembodied, almost entirely transparent creature with enormous open wings, holding the artist's head in his hands, while the latter's body is lying decapitated at his feet. Headless, with broken hand gestures, it looks completely defenceless; however, the angel's wing is spread over it like protective armour.

In another biographical painting by Popkov, My Day (1968), one can see how the coordinate system completely collapses, and three images appear in inking, like fresco images, acquiring a symbolic meaning.

The painting Northern Chapel (1973) is another example of a painting on a religious theme in Viktor Popkov's work. The main character here is a little boy who is also the viewer. Placing the boy's figure in front of an open door in the sacred space of the chapel, the artist thereby focuses attention on "the adolescent's entry into the church, communion with the spiritual".

In the initial sketch of the painting Northern Chap$e l$, the boy (we see only his head) is standing in the 
centre of the church next to the iconostasis, under the dome, painted with colourful frescoes and occupying most of the composition. A jubilant mood prevails: the iconostasis is festive with colours; the sky-blue with red details of saint figures dome, divided into sectors, seems to be radiant and resembles the sun. The artist chose such a perspective that the viewer feels like looking at the dome with his head thrown back, feeling slight dizziness and understanding what is happening in the boy's soul. In the final version, there are figures depicted above the entrance to the chapel. The composition is designed in such a way that guardian angels, having flown to the entrance to bless the boy and everyone entering, are seen in these figures. The chapel's space is perceived as the house of God ascended above the earth, the beauty of which the boy marvels, and the doorway seems to be a window from heaven to earth.

Another painting by Popkov, Grandma Anisya was a Good Person, became iconic in this topic. To enhance the planar effect, more vividly presenting the main group of characters, the final version of the picture was painted not with oil paints but with tempera. However, the focus on the essentials did not, of course, underestimate the details. According to the artist, it was the opportunity to examine the details that was supposed to make the space of the painting closer, even dear to the viewer, and also provide the key to understanding the general concept of the work. The artist's notes contain the following inscription: "To paint Grandma Anisya as a coloured engraving and an icon... Faces as in icons ochre, moulding, highlights." Indeed, this icon style can be felt when looking at the painting: the characters, side by side in tears, resemble figures from icons, the silhouette of the figure in a light raincoat depicted from the back is like the silhouette of an angel, and in general, the motif of mourning, a farewell is like in icon painting. The Dormition of the Mother of God is involuntarily recalled as a possible prototype. It is a fundamentally different language - the language of metaphysical concepts, which is timeless for any century.

It is interesting that, referring to the problem of the spiritual origins of art in the 1960s, A. Morozov emphasised the inner artistic relationship of Korin and Popkov: "It is curious to note that Popkov's formation took place not without the indirect influence of P. Korin. The middle of the 60 s is the peak of the old master's popularity, associated with the release of his cycle Rus to the public. The heroines of the painting Memories. Widows (1966-1968), the first masterpiece of mature Popkov, involuntarily echoed Korin's characters. They were perceived as a powerful historical and national type, which had no other analogy in our painting." In the artist's archive, a photograph was found. It captured Viktor Popkov among those present at the funeral service for Korin in the Assumption Cathedral of the Novodevichy Convent. This emphasises the inseparability of spiritual and artistic traditions, despite all the efforts of the Soviet authorities to wipe out the legacy of the past and build socialist realism from scratch.

Nikolai Andronov's works, in which the artist indirectly used biblical motifs and Christian iconography, are examples of the appeal of the severe style artists to religious issues. By building the subtlest associations, complex hints, using iconographic principles, he created a kind of interweaving, a connection between the Gospel stories and the life of an ordinary village. Andronov's metaphorical meaning does not always lie on the surface; however, on the other hand, it is obvious to the aware viewer. For example, in the painting Likbez (1972), teaching to read and write the villagers is perceived as the New Testament scene The Last Supper widespread in religious art, and in the painting Family (1976) - the gospel story Christmas.

In Likbez, such an allusion is indicated by the number of participants, fine-looking, as if copied from icons, the appearance of peasants, imitation of azure highlights on their clothes, the characteristic plasticity of the characters. It is also worth paying attention to the space between the two central figures sitting with their backs to the viewer in the foreground: their outline resembles a goblet - a motif common in icon painting and serving as a reminder of the Eucharistic bowl. Also, a detail such as the image of a dog in the lower right corner appears. In the compositions of The Last Supper, the dog is often placed next to Judas, who is always isolated from the disciples using various pictorial techniques, for example, the colour of his clothes. In those cases, when all the disciples are depicted with halos, his halo could be painted in black or be completely absent... All this can be attributed to the figure in Andronov's painting, sitting with his back to the dog; compared to other heroes, the artist highlighted the scarf with dark colour. Thus, through comparison with one of the divine sacraments, teaching peasants to read and write is perceived as a process 
of their introduction to the world of spiritual culture. The artist conveyed the state of comprehension of the secret, the transformation of ignorant peasants into initiated ones.

In the painting Family, the artist is attentive to every detail of the painting and deduces from a seemingly everyday motif the image of a biblical event. Thus, village life takes on a special meaning. The male character can be perceived as Joseph the carpenter and as a simple peasant, and the female image as Mary or as a peasant woman. Two sources of light can also be seen: the open door and the mystical light from the nursery. The emergence of a surreal source can be associated with the traditional iconography of the Christmas plot.

In Andronov's village series, a window acts as a connecting link between the human world and the natural world, connecting the world of everyday life with the spiritual world. On the other hand, the window frame becomes a kind of border between man and immense nature. In this sense, Andronov's series of windows becomes a symbol of that secluded, contemplative life filled with inner work that the artist had in Ferapontovo.

Nikolai Andronov has self-portraits against the background of icons. Their paradox lies in the fact that it is difficult to name another work in our art, where a person of the generation of the 1960s is so clearly recognised. In Self-Portrait in a Museum, the hero in his cross-patterned sweater, as on the robes of a saint, belongs in spirit to the same soil that created the ancient iconic image.

The figurative world of Nikolai Andronov's painting appeared, as a rule, in substantial and concentrated forms. With the naked eye, it is possible to notice the plastic, spatial-compositional and spiritual bonds that permeate this wholeness, accumulated by the master's creative and life experience. The master's comprehension of the landscape of the $19^{\text {th }}$ century, the heritage of the Russian avant-garde of the early $20^{\text {th }}$ century, painting of the 1920 s was combined with a deep interest in frescoes (Dionisius).

The artist was alien to underestimating our spiritual tradition, including church tradition, and folklore, and ancient architectural monuments - the churches that he painted so often and earnestly, and the memory of his beloved Dionisius, and the icons that he closely examined both in a museum and in a village hut. For Andronov, all this is not just a grain of memory but, to a great extent, the work of the soul and a test of living human conscience.
Like the painting of other severe style representatives, Geliy Korzhev's painting is largely cleared of minor details, and his characters do not belong to this century. Korzhev's environment is conditional to the same extent as the landscape of an icon. And the generalised human figure from hundreds of his paintings is a portrait of the people, through which the era is refracted in his painting.

Traces of War is the central, most famous painting in the artist's work. A portrait of a soldier looking directly at the viewer with a single piercing blue eye, with an innocent face covered with thin burnt skin. A disabled, dirty man, burned by fire and sun. If one closes one part of the face, a dead man with a pointed nose will be seen; the other part portrays a living, strong person. It is almost an icon - a fullface, no emotion, no background - the reality in which it is located is not specified. Traces of War is like a negative of Dürer's painting. The same monochrome background, only dark. The human face is iconographic and beautiful.

Korzhev outlived the country where he was recognised, took its collapse hard; however, he also changed himself, leaving the previously important and relevant topics and mastering new ones. It is interesting that, not being a churched person, after the death of his parents, he turned to biblical stories. And this only helped him in his work. Nevertheless, the artist hardly changed the techniques developed in his youth. In the 1964 painting, the mother is painted in much the same way as the mother in Carrying the Cross from the 1999 biblical series.

The artist worked on this series for a quarter of a century - from the mid-1980s to the end of his life. Starting to develop the biblical series, or even a little earlier, Korzhev moved away from active social activities and became almost a hermit. The master's address to the biblical topic was a continuation of his reflections on the main spiritual, moral and philosophical problems and was realised with remarkable directness. In the interpretation of the plots of the Old and New Testaments, the construction of the internal logic of the narrative, proceeding from ethical and moral concepts that determine the actions of a person, was the main point for Korzhev, an artist-thinker, wise with a rich life experience.

Religious and philosophical issues also appear in the village series by Pavel Nikonov. One of its ideas was to embody the plots of Scripture in daily sketches, which, through iconographic associations 
with biblical scenes, lose their straightforward interpretation and acquire additional meaning. Nikonov generalised the figures to the state of signs and brought the landscape to the state of conditional icon-painting hills. This transfer of evangelical events to a specific dimension was not something unique: according to Nikonov, when he conceived a series of paintings on a biblical theme, he recalled the work of the Dutch master, Pieter Bruegel, the Elder.

Pyotr Ossovsky found his spiritual homeland on the land of the ancient Pskov region with its pristine beauty and harsh epic grandeur, amazing nature and courageous people, which is reflected in many of his thematic paintings, close to iconic images. In the portrait images: Ascetic, Pskovite Woman, Huntsman Mikhail, Vasilisa, Siberian Old-timer, Mother and Father, he noticed features that testify to the moral purity of the Russian person, the integrity of the personality, about serving his land and faith in your destiny. The series of self-portraits that the master painted throughout his life is of particular importance. The latest of them is Self-portrait. White Square of the Canvas, in which the artist portrayed serious reflections on the fate of a creative person in society, their role and significance.

The land of ancient Pskov, which Ossovsky called his spiritual homeland, became a source of images for the artist that reflected not only the national identity of the Russian province of the middle of the last century, its unique patriarchal atmosphere and originality but which also turned out to be astral - outside of time and certain space.

The heroes of Viktor Ivanov's works are ascetic and austere; the paintings are monumental. The influence of icon painting, which many artists of the severe style were fond of, same as the avantgardists before (it was not in vain that Ivanov studied in the workshop of Alexander Osmerkin, a Jack of Diamonds artist), is evident in them.

One of Ivanov's best paintings is Family. 1945 (1957-1964), which tells about the first days of a peaceful life after the victory over fascism. His canvas is a typical example of the severe style, depicting a solemn peasant meal, where deep tenderness and joy of the newly acquired integrity are hidden behind the external restraint of emotions.

He remained faithful to the peasant theme in his latest works and is just as indifferent to the time frame. His Mowers (1991) in white shirts could have been painted in the 1970s, and the peasant women with icon-painting faces in the Ryazan Fields (2005) cleaning the haystacks seem to be frozen in eternity.
Ivanov's landscapes represent a mysterious and boundless world; nature in them becomes a prayer image. An image of a church on a high bank in the background is one of the frequently recurring motifs of his panoramic landscapes. This elevation, as the foundation for the church, is as if a solid foundation of faith.

There is an internal, spiritual connection between Viktor Ivanov's paintings. In them, he reflected the stability, value of life phenomena. Hence the composition, the power of colour, the fullness of the entire form. The artist's works are dedicated to the people of the modern village; however, he was not a painter of everyday life. Village life, the work of people - this is a theme permeated with a single concept, through which Ivanov brought his views on the world to the viewer, expressed the ideas of the time, asserted his ideals.

Many critics rank Dmitry Zhilinsky among the artists of the severe style. However, the artist himself believed that he "only lived at the same time as them". Nevertheless, the artist had much in common with his colleagues in the movement. In his work, Zhilinsky turned to the legacy of Old Russian icon painting and the Italian and Northern Renaissance. Every phenomenon, hero or object in his paintings hides a whole story, full of metaphorical assimilations, symbols and allegories. The works of this master are characterised by saturation with symbols; there are no random details in his paintings.

The image of his mother, Anastasia Fedorovna, is one of the most heartfelt images in Zhilinsky's work. It is most vividly presented in the painting Under an Old Apple Tree (1969), dedicated to the tragic history of the artist's family. As a basis, Zhilinsky used a board, preparing it like for an icon. In the ark - a deepened centre field on the front side of the board, he depicted his mother and children, and in the margins, he placed the figures of his father, who was shot in 1937, and his brother, who died during the war in $1944 \ldots$ The comparison of a fruit-bearing tree and a woman surrounded by grandchildren becomes a metaphor for an indestructible vitality. In its wide flat frame painted with white paint, with two images placed on it, the painting evokes ancient Russian icons with images in the margins. The technique in which the work was done (with tempera paints on gesso) also comes from Old Russian icon painting.

The etching The Sistine Madonna by Vladimir Daichman, made in the spirit of the severe style, is extremely expressive. The vertical format of the sheet 
emphasises the narrow space of the bunker, where the canvases are stored in barbaric neglect. Dusty stairs lead up. A Red Army soldier with a submachine gun is standing there, in the opening of the door. Rays of sunlight highlight the face of the Madonna and child out of the darkness. The dynamism of the scene is given by the reversal of the soldier's figure, the contrast between the bright light pouring from the outside and the darkness of the room, the special character of the stroke. This painting is a symbol of the constant struggle of Soviet barbarism and rejection of traditions against the eternal beauty of iconic images and great paintings that have become iconographic.

Unfortunately, the severe style, that arose in spite of the endless images of jubilation of Soviet holidays and ceremonial portraits of leaders, had its weaknesses. Over time, many of its adherents became hostages of their own artistic program: the search for laconic simplicity often led to a certain emasculation and schematisation of images, and the desire for monumentality sometimes turned into indifference to details and exaggeration of the depicted. Paradoxically, over time, the masters of this style, who initially set themselves the goal of reflecting the truth of life, increasingly began to create a kind of work mythology in their works, in fact, falling into the same myth-making that they once fought against. The newfound novelty, a fresh outlook on life degenerated into a cliché over time.

However, the best works of this movement, in which the connection with icon painting is especially clearly traced, are remarkable examples of creative freedom. In them, the artists did not look back at the ideological guidelines; for many of them the Russian icon with its pure colours, laconicism, truth was a creative beacon. It was these features that the representatives of the severe style endowed the paintings that became a phenomenon of the Soviet era in the 1960s-1970s and made their way to the viewer, like the light of an icon breaks through the walls to a believer.

The images in these works are not individualised but rather generalised. Nevertheless, this does not interfere in any way with understanding the state of mind of the characters; maybe, on the contrary, it makes it more pure, detached from concrete signs of reality, and therefore deeper. In these painting, artists' desire to display the inconceivable naturally becomes akin to the tasks that Russian icon painters have faced for centuries.

Through metaphorical pictorial language, artists of the severe style returned the original traditions of Russian life, in which the icon was always the central axis and the basis that binds the foundations of spiritual life, to the Soviet people, torn from their roots.

However, the similarity with the icon was not only in pictorial, spiritual and philosophical senses but also manifested itself in the social role of large paintings of the severe style painters, which became a good examplel. Monumentality, posterity, large format, laconicism and expression - all this gave the paintings an acutely relevant and, at the same time, epic, highly civic meaning. The paintings undoubtedly greatly influenced the cinema and painting of the following decades, raising new questions of a moral and ethical sense.

Being Russian by birth, the severe style artists, perhaps without knowing it, reached the level of great national artistic generalisations, made by them on the basis of purely Russian material, based on their own experience and knowledge of their people's lives.

The severe style is a phenomenon that was so categorically assigned the status of something episodic, even fleeting, turned out to be, in different versions, compatible with philosophical and religious postulates that are relevant at all times, with a national idea and an attraction to eternity.

\section{REFERENCES}

1. Alekseeva, T. P. 2017. "Images of the People and the Fate of Individuality in the Severe Style Painting", Cultural Heritage of Siberia, vol. 3, no. 21, pp. 40-45.

2. The Bible Through the Eyes of a Socialist Realist. Geliy Korzhev. Exhibition catalogue, December 12, 2012 May 27, 2013, Moscow.

3. Bobrikov, A. A. 2003. "The Severe Style: Mobilisation and Cultural Revolution", Art magazine, no. 51-52, pp. 29-33.
4. Bondarenko, L. K. 2005. The Theme of the Village in the Works of Soviet Painters of the 1960s-1970s, Thesis of the Candidate of Art History: 17.00.04 [Place of thesis defence: Moscow Surikov State Academic Art Institute]. Moscow

5. Burganova, M. A. 2008. "The Severe Style: Direct Speech", Art Literature Scientific and Analytic Journal Burganov House. The Space of Cultur, no. 1, pp. 8-33. 
6. Butkevich, D. 2006. "With a focus on the Severe Style", Nezavisimaya Gazeta. January 27, p. 3.

7. Dekhtyar, A. A. 1981. Pavel Nikonov. Leningrad: Artist of the RSFSR, p. 69

8. Zaitsev, E. V. 2000. Geliy Mikhailovich Korzhev: On the Occasion of his 75 ${ }^{\text {th }}$ Birthday, Moscow, p. 111.

9. Victor Popkov [Text] / [text: P. Kozorezenko; photo: V. Kubarev]. Moscow, 2012. P. 457, [6]: illustration.

10. Voloshina, I. 2015. Victor Popkov: An Artist on the Widow's Land. Foma, no. 12. pp. 62-71.
11. "Time of Change: Art of 1960-1985 in the Soviet Union." [Catalogue] State Russian Museum. St. Petersburg: Palace Editions, 2006. P. 415: illustration.

12. Matthew Cullerne Bown. 1991. Art under Stalin. Oxford, Phaidon Press.

13. Realismi Socialisti. Grande Pittura Sovietica 1920-1970. Milano, Skira, 2011. 


\section{ОБРАЗ ИКОНЫ В ТВОРЧЕСТВЕ ХУДОЖНИКОВ «СУРОВОГО СТИЛЯ»}

\begin{abstract}
Аннотация. Важным импульсом творчества мастеров «сурового стиля» стало обращение к художественным традициям разных эпох - их своеобразное восприятие приёмов постимпрессионизма, наследия русского авангарда, искания советских живописцев 1920-1930-х годов, а также искусство Проторенессанса и Древней Руси. При художественных экспериментах и активном обращении к разным изобразительным линиям они умело соединяли в своих произведениях опыт древнерусского искусства, накладывая традиции иконы и фрески, живопись примитивизма на современные лекала.

Скрытой, не явной доминантой творчества мастеров «сурового стиля» стало древнерусское искусство и его главное воплощение - икона. Вершиной мастерства для представителей этого направления была деятельность выдающихся иконописцев прошлого (Феофана Грека, Андрея Рублёва, Дионисия), которые в своих произведениях воплотили новое, возвышенное понимание духовной красоты и нравственной силы человека.

Художников «сурового стиля» привлекали в русской иконе локальные цвета, упрощённая композиция и формы, «застывший» сюжет. Ещё более влекла их цветовая насыщенность, радостная сила или суровая мощь чистых красок. Однако связь с иконописным
\end{abstract}

Кардинальные метаморфозы духовной и нравственной жизни народа в годы Великой Отечественной войны положили начало новому этапу в художественной практике мастеров искусства, обострили их восприимчивость к скрытым элементам и веяниям действительности.

Поиски привели к утверждению нового героя - современника-созидателя, внутренне собранного, демонстрирующего твёрдость нравственных принципов, готового к труду и борьбе. Самоценность живого человека, очищенного от искусством - не только в технических аспектах живописи. В произведениях художников «сурового стиля» также, как в иконе, эмоциональное напряжение сосредоточено на внутренней жизни, а не выражается внешней экзальтацией.

Обращение к иконописи не было случайным: художники ощущали печальный распад связи поколений, трагический слом вековых устоев, богооставленность и... отчаянную тоску по какой-то другой, нездешней Правде. В этих голосах эпохи - вся сложность внутреннего самоопределения поколения 1960-1970-х. Представители «сурового стиля» старались раскрыть тему Света и Смысла, насколько это было возможно в условиях советского времени. Правда этого поиска выплеснулась на их холсты.

«Суровый стиль» — явление, которому так безапелляционно присваивали статус чего-то эпизодического, даже мимолётного, оказалось в разных вариантах совместимым с актуальными во все времена философскими и религиозными постулатами, национальной идеей, влечением к вечности.

Ключевые слова: суровый стиль, русская икона, религиозный сюжет, аскетичные лики, нравственная сила, правда жизни, Попков, Никонов, Коржев.

идеологической шелухи, привела художников к разработке темы человека и его места в современном мире. Молодым мастерам хотелось показать героя трудовых будней крупным планом в типических обстоятельствах своего времени.

В живописи новый специфический способ раскрытия внутреннего мира героя обозначался в сокрытии духовной энергии и потенциала в лаконичной форме, суть передавалась посредством поиска взаимосвязи между внешним обликом и внутренним состоянием человека, появилась 
новая трактовка пространства и времени, сами произведения стали отличаться широтой идейных обобщений. Общая цель, сплотившая большую группу художников, породила общность эстетических принципов и формальных приёмов и позже была условно названа «суровым стилем».

Живописцы ощущали изношенность «старых» технических средств и композиционных систем, отрицая пассивность «парадных» произведений искусства, поэтому они обратились к поиску новых художественных приёмов, которые смогли бы пробудить интерес и вовлечь зрителя в увлекательный процесс поиска духа времени и утверждения обновлённого человека, стремясь подтолкнуть к сопереживанию содержания своих работ. В работах будущих «суровостильцев» - П.П. Оссовского «У переезда», Г.М.Коржева «В дни войны» и В.Ф. Стожарова «За дровами», представленных на первой молодёжной выставке, искусствоведы и зрители почувствовали смену интонационного строя в восприятии окружающей действительности - сдержанность, сосредоточенность, лаконичность, достоверность.

Ведущими качествами поколения являлись уникальный жизненный опыт, нетерпимость ко лжи, созидательное начало, осмысленный подход к творчеству, твёрдая гражданская позиция и бесстрашие. Художники не разрывали связь с предыдущим наследием, а вычленяя всё самое ценное, идеологически незамаранное, складывали из этих составляющих новое искусство, давая свою нравственную оценку современности и недавней истории. Они хотели сказать своё слово и быть услышанными, поэтому каждый боролся за собственное творчество до конца.

В попытке уловить нерв времени «суровостильцы» отправлялись «документировать» действительность в самые природно-недружелюбные уголки страны. Поиск настоящего человека, трудящегося в тяжёлых условиях, проводящего каждый день в борьбе со стихией, стал диктовать свой новый изобразительный язык: пренебрежение красотой натуры, некоторая условность и графичность её изображения, сдержанный колорит, монументально-плакатные лаконичные формы, особый типаж героев и внутреннее эмоциональное насыщение полотен (энергичность, сдержанность, дерзость, преодоление, драматизм), эпическое звучание представленных художником сцен.

Художники сурового стиля стремились противопоставить своё творчество официозному па- фосу плаката и официально-имперской стороне социалистического реализма. Уже в контексте их раннего творчества постепенно вырабатывались такие параметры «сурового стиля», как изображение неприукрашенной реальности, отход от подробного литературного повествования, стремление к психологической трактовке образов, метафоричность художественного языка, расширяющая смысловые границы произведения.

Эта обезоруживающая беспафосность действовала сильнее, чем надоевшие клише изображения «творческого человека», более того - в ней была своя негромкая жизненная подлинность, ведь существование художника состоит из таких рядовых ситуаций, вполне будничных, но при этом наполненных сокровенной внутренней жизнью, чудесным образом разрешающейся произведениями искусства.

В центре внимания «суровых» - тема рабочих будней, поэтизация повседневного труда человека. Самое прозаическое и обыденное становится предметом монументализации и гордого возвеличивания. Их персонажи - люди брутальных профессий - строители, геологи, ремонтники, плотогоны, полярники. Они одновременно имеют и индивидуальные портретные черты, и формируют собирательный образ мужественного героя. Всё в этих персонажах говорит об их непростой жизни, упорстве, духовной и физической мощи.

Новый стиль демонстрирует протестантский тип героя - взрослого и ответственного, обладающего собственным опытом, личной верой и вообще развитой внутренней мотивацией (и потому не нуждающегося во внешнем идеологическом стимулировании со стороны партии), хотя и действующего в рамках общего преобразовательного проекта. Художники смогли на время оглядеться, понять время и самих себя, убежать от оскорбительной фальши советских идейно-воспитательных ритуалов, от столичных витрин коммунистического процветания во внутренний мир простого человека.

«Суровые» в большей степени поглощены отображением внутренней, духовной работы персонажей, чем описанием окружающей их действительности. Больше всего в трактовке внешнего облика героев художники уделяют внимание лицам и рукам персонажей, так как именно они и их взаимодействие проявляют внутреннее состояние человека. Хотя порой в полотнах «сурового стиля» представали не лица отдельных людей, а одухотворённый лик целого поколения. 
В соответствии со своим миропониманием и общим впечатлением эмоциональной напряжённости «суровые» избирали и художественные средства. Художники П. Никонов, В. Попков, Г. Коржев, братья А. и П. Смолины, П. Оссовский и другие в поисках «правды жизни» обратились к сдержанной, условной, обобщённой форме, отвергнув всякую описательность. Зачастую художники работают большими плоскостями, используют жёсткие пластические формулы, укрупняют и уплощают изображение. Произведениям присущи такие художественные особенности, как лаконизм, ритмичная, но уравновешенная и монументаризированная, преимущественно фронтально развернутая композиция с острыми линейными ритмами, чёткая очерченность контуров, конструктивная лепка формы, экспрессивность, колористическая сдержанность с лапидарными цветовыми пятнами. Колорит, как и вся атмосфера их полотен, подчёркивает суровость темы и образов героев, акцентирует аскетизм и духовную насыщенность, глубину. В картинах преобладают оттенки чёрных, коричневых, землистых цветов и другие минорные тона. Крупные планы, провоцирующие вглядывание в героев. Эти картины очень близки изобразительным традициям древнерусской иконы и ранних русских «персонных» портретов XVII в.

Важным импульсом творчества мастеров «сурового стиля» стало обращение к художественным традициям разных эпох - их своеобразное восприятие приёмов постимпрессионизма, наследия русского авангарда, искания советских живописцев 1920-1930-х годов, а также искусство Проторенессанса и Древней Руси. При художественных экспериментах и активном обращении к разным изобразительным линиям они умело соединяли в своих произведениях опыт древнерусского искусства, накладывая традиции иконы и фрески, живопись примитивизма на современные лекала.

Художники вдохновлялись их шедеврами прошлых столетий и как будто находились в постоянном внутреннем диалоге с мастерами, чьё наследие столетиями являлось источником плодотворных идей в русской живописной культуре и не могло быть уничтоженным за несколько десятилетий.

Изучение творчества мастеров прошлого значительно расширило стилистически и тематически границы творчества советских художников.
Немалую роль в переоценке прошлого и настоящего сыграли искусствоведческие исследования, «реабилитировавшие» целый ряд мастеров, творчество которых долго считалось не заслуживающим внимания.

Программные произведения «сурового стиля» - «Плотогоны» Николая Андронова и «Геологи» Павла Никонова - демонстрируют разнообразие источников. И если в «Плотогонах» цветовые эффекты Петра Кончаловского сочетаются с мотивами Александра Дейнеки, то в «Геологах» актуализируется традиция Павла Кузнецова с проекцией на иконописную стилистику Дионисия, что в глазах советских идеологов начала 1960-х годов выглядело абсолютной крамолой. Сам факт обращения «суровых» к запрещённым ранее традициям уже воспринимался современниками как радикальный новаторский жест, хотя в живописи 1960-х годов уже чувствуется определённая исчерпанность и «усталость» тематической картины.

В работах Виктора Попкова, Виктора Иванова, Дмитрия Жилинского, Татьяны Назаренко очевидно обращение не только к ближним, но и к дальним традициям - древнерусской иконописи, искусству раннего Ренессанса, примитивам XVIII века.

Скрытой, не явной доминантой и маяком, к которому обращались мастера «сурового стиля», стало именно древнерусское искусство и его главное воплощение - икона. Иконопись веками служила отправной точкой русского искусства и незримой нитью, связывающей мастеров живописи с их разными стилями, творческими устремлениями... Она служила невольным образцом, каноном, порой интуитивным, для разных поколений русских мастеров кисти. Вершиной мастерства для многих советских художников была деятельность выдающихся иконописцев прошлого (Феофана Грека, Андрея Рублёва, Дионисия), которые в своих произведениях воплотили новое, возвышенное понимание духовной красоты и нравственной силы человека.

Художников «сурового стиля» привлекали в русской иконе локальные цвета, упрощенная композиция и формы, «застывший» сюжет... Ещё более влекла их цветовая насыщенность, радостная сила или суровая мощь чистых красок.

Например, ранние образцы рублевской иконописи соответствуют общим правилам, которых придерживались мастера «сурового стиля». 
На православных образах XIV-XV веков принято было изображать суровые и аскетичные лики с характерными византийскими чертами: большими глазами, высоким лбом, прямым носом и тонкими губами. Мастера использовали в основном сдержанные, тёмные цвета: тёмно-красный, коричневый, охристо-жёлтый.

Ранние работы Рублёва иконописец и реставратор начала XX века Василий Гурьянов описывал так: «..лики написаны тонкослойно с соблюдением крайней последовательности в переходе от освещённых мест к неосвещённым, выглядят определённо зеленоватыми в тенях и моделированы коричневой («тёмной») охрой без отметок, т.е. без ударов на наиболее светлых местах для обозначения белою краскою бликов; в соответствии с ликами так же слабо моделированы и фигуры, а контур обозначен лишь тонкой описью».

Связь с иконописным искусством была не только в технических аспектах живописи. В произведениях художников «сурового стиля» также, как в иконе, эмоциональное напряжение сосредоточено на внутренней жизни, а не выражается внешней экзальтацией. Эта живопись, скорее, об удивительной взвешенности всех линий и деталей, о внутреннем балансе, о точно выверенной линии центра на мастерски написанных образах... В этом смысле художники «сурового стиля» были наследниками традиций русской живописной школы изображать суровые и аскетичные лики.

Очевидно, что невольное обращение к иконописи не было случайным: художники ощущали печальный распад связи поколений, трагический слом вековых устоев, Богооставленность и... отчаянную тоску по какой-то другой, нездешней Правде. В этих голосах эпохи - вся сложность внутреннего самоопределения поколения 1960-1970-х.

Никто из художников не был церковным человеком, да и это было невозможным в советское время. Однако существовала духовная, «корневая» связь с родителями, выросшими в вере, с художественными традициями. Этот христианский подтекст, скорее, просвечивает, нежели явственно проговаривается, что было очевидно в эпоху тоталитарного атеизма. Думается, что главным здесь было собственное постоянное стремление «вгрызаться в жизнь, узнавать, постигать основные законы нашего бытия» (В. Попков).

Это не были напрямую религиозные сюжеты, но в этих темах художники затрагивали что-то неизбежно важное, «сущее» во внутренней жиз- ни каждого человека. В своих главных работах художники пытались интуитивно пробить границу некой духовной тесноты своего поколения, о которой образно написал В. Высоцкий: «И снизу лёд, и сверху...»

Представители «сурового стиля» старались раскрыть тему Света и Смысла, насколько это было возможно в условиях советского времени. Правда этого поиска выплеснулась на их холсты. Они по-особому понимали, интуитивно ощущали незримую связь времён, преемственность поколений и традиций.

Традиция религиозного русского искусства была прервана после 1917 года. Интересно отметить, что иконы при этом, как часть культурного наследия, стали объектом научных исследований. В то же время, атеистическая политика государства, накладывая запрет на религиозную тематику и сюжеты, не мешала художникам, создававшим в своих работах образ нового человека, прибегать к формальным заимствованиям, идущим от иконописи: свет, струящийся на изображаемую модель отовсюду и будто исходящий из неё (трансцендентный свет), поза предстояния, вид анфас.

Хотя традиция иконописи в советский период, казалось бы, прервалась, художники «сурового стиля» исподволь искали выхода своим творческим замыслам и разговора похожим живописным языком, продолжая многовековые традиции иконописания, возможно, неосознанно, на время заменяя иконописное искусство и интерпретируя его в соответствии с жизнью советского времени.

Произведения мастеров «сурового стиля», связанные с религиозной проблематикой, составляют особую страницу их творчества. Они стали продолжением размышлений художников о важных нравственных и философских проблемах, а также острой внутренней потребностью обратиться к истокам - канонам живописного мастерства, коими во все времена считалась иконопись.

Обращение к этой теме кажется неожиданным лишь на первый взгляд: с одной стороны, это был способ выразить свой протест и неприятие существующей идеологии и порядков. С другой стороны, художников привлекали монументальные росписи храмов, чистота и ясность цветовой палитры иконописцев XV-XVI веков, своё вдохновение они черпали и в житийных иконах XVII века, их образном строе и стремлении к иносказанию. Появившаяся в завуалированной форме в пейзажных и жанровых полотнах, эта тема сформировалась и проявилась 
в «деревенских сериях» мастеров и стала продолжением их размышлений о важных нравственных и философских проблемах времени.

Её восприятие и интерпретация получают индивидуальное художественное воплощение в творчестве каждого мастера. Но в то же время, обнаруживаются и черты общие, объединяющие художников, которые позволяют в целом судить о том, как решается религиозная тема в творчестве «суровых». Одним из путей или способов раскрытия религиозной проблематики становится включение в композицию ассоциирующихся с религиозным искусством знаков или символов, которые и являются источником дополнительного, «зашифрованного» смысла. Произведение становится многозначным, его идеи не лежат на поверхности, а скрыты в художественном плетении полотна. "Для меня, как и для многих художников моего поколения, - отмечал Виктор Иванов, характерно, что сами «размышления» художника в готовом виде в картине не показаны. Они как бы вынесены за пределы полотна и должны возникнуть у зрителя».

Появление данной темы в творчестве представителей «сурового стиля» проистекает в какой-то мере из закономерностей общечеловеческих: в определённый момент жизни человек начинает задумываться о ценностях вечных, непреходящих. Результат сложной внутренней работы - достижение определённого жизненного этапа, нового уровня самосознания художников - привёл к тому, что вопросы о смысле и сущности бытия стали краеугольными в их творчестве. Симптоматично, что каждый из них искал свой мир сакральных образов вдали от столицы: Николай Андронов работает в Ферапонтово, Виктор Иванов - в своем родовом селе в Рязанской области, Виктор Попков путешествует по Русскому Северу, для Павла Никонова творческой лабораторией на долгое время становится деревня Алексино Тверской области, а Пётр Оссовский связал своё творчество с псковской землей.

Изоляция от суеты современного города, уединение, погружение в себя - в этом видится образ жизни отшельника, занятого духовным поиском, который, среди прочего, наводил мастеров на размышления и переживания религиозной направленности.

Самое сильное восприятие и творческое перерождение иконописи в современной форме проявилось, пожалуй, у Виктора Попкова.
В творчестве художника существовала глубинная связь с древнерусской иконописью, с образами, созданными Дионисием и А. Рублёвым. Многие известные картины Попкова создавались под прямым воздействием русской иконы, о чём можно прочитать в его дневниках. Самое сильное впечатление художника от русского искусства - было именно от иконы, а среди икон от произведений Андрея Рублёва.

Даже один из первых автопортретов Попков построил в иконописном стиле. В 1959 году у художника случилась поездка в ПереславльЗалесский на творческую дачу. А. Тутунов вспоминал, что первой работой, которую ему показал Виктор Ефимович, был автопортрет: на картоне, разлинованном на квадраты, в центре был изображен сам автор, а по бокам, как клейма вокруг средника в иконах, - впечатления от Переславля.

В 1964 году художник специально ездил в древний монастырь Ферапонтово, чтобы сделать этюдные зарисовки с фресок Дионисия. Художнику нравились их плавные струящиеся линии, мягкие сочетания светлых, чуть разбеленных, тонов и спокойный, словно напевный ритм. Именно тогда Попков начал много писать в технике темперной живописи.

Приёмы, восходящие к русской иконописной традиции, полюбились Попкову и позднее не раз использовались им в работе. Отголоски ферапонтовского опыта чувствуются, например, в высветленной палитре «Бригады», в изображении исключительно высокого - иконного - горизонта, в спокойном кругообразном ритме, создающем ощущение единства и согласия, в уходе от пространственной глубины, в чертах, которые роднят это полотно с работами Д. Жилинского, к творчеству которого Виктор Ефимович в то время относился с особым вниманием.

Попков, как и великие мастера прошлых веков, нередко вдохновлялся работами других художников, ведь это никогда не было прямым заимствованием, но всегда переосмыслением, в котором от творческой индивидуальности самого Попкова было больше, чем от первоисточника. Ещё одна очевидная аналогия - работы палехских мастеров, в свою очередь также восходящие к иконописи: именно в то время Попков по-настоящему рассмотрел и полюбил утончённую декоративную изысканность лаковой миниатюры Палеха.

Виктор Попков, довольно быстро проживший в своём творчестве проблематику сурового стиля 
и ушедший дальше в работах, которые не сводятся к тому или иному направлению, считается классическим, лучшим представителем «суровых» во многом благодаря картине «Строители Братской ГЭС».

По словам В. Барвенко, приехавшего в Братск вместе с Попковым, тот был буквально одержим образами рабочих, рисуя этюды с утра до вечера. Загоревшись целью создать по-настоящему монументальное произведение, он стал работать ещё напряжённее, чем обычно. Идея использовать в произведении тёмный - ночной - фон возникла сразу, поэтому этюды к картине писались ночью. По словам самого художника, замысел картины был основан на желании «сделать как в иконах, всех силуэтами на чёрном фоне». Оттого и получились в картине монументальные, «иконные» фигуры рабочих.

В похожем ключе решена ещё одна замечательная работа Попкова - «Бригада отдыхает» (1965), получившая признание в Париже. Её герои не действуют, а пребывают в пространстве картины, погружённые в свои неспешные занятия - чтение, игру в шахматы. Выразительные приёмы здесь ещё более отточены, чем в предыдущем случае: перспективные сокращения отсутствуют (вместо этого фигуры переднего плана помещаются в нижнюю часть композиции, а более удалённые - в верхнюю), а скошенное поле, на котором лежат рабочие, уподоблено условному плоскостному золотистому фону, придающему этой картине сходство - неслучайное - с иконой.

В одном из номеров журнала «Творчество» тогда было напечатано обсуждение картины «Бригада отдыхает» по итогам профессионального круглого стола: некоторые художники высказались недоброжелательно, многие просто недопоняли это произведение. Но сейчас, спустя полвека, очевидно, что находки Попкова не только представляли художественный интерес, но и восстанавливали ещё недавно казавшуюся полностью утраченной возможность диалога с древнерусской традицией. Причём дело было не в заимствовании отдельных мотивов (у Попкова тогда преобладали темы вполне современные), а в попытке осмыслить художественный язык иконописи структуру изобразительного поля, колористические закономерности и т.д.

Особой иконографией пронизана серия «мезенских вдов» Попкова. В центре полотна «Вдовы» изображена в полный рост высокая худая жен- щина, её скорбное лицо с глубокими морщинами напоминает иконный лик или лицо древней деревянной статуи, оно обращено к зрителю, но сдержанная в эмоциях и полная грусти женщина погружена в собственные мысли и воспоминания. Кажется, будто героиня картины сошла с иконной доски, воскрешая в памяти древние иконописные изображения святых мучениц. Это самая яркая фигура из всех, строгая и величественная, она словно колонна держит на себе всю картину. Интуитивно, на ощупь Попков подходит к теме христианского смиренного принятия и несения своего креста.

В натюрморте с серым лоскутным одеялом Попкова примечательно появление иконы, с одной стороны, вроде бы символизирующей связь с традициями, а с другой, - решённой неожиданно нетрадиционно. Приглядевшись к ней, понимаешь, что не можешь узнать изображенный сюжет, что иконографии такого рода не существует и что она, очевидно, целиком придумана художником, возможно, как намёк на необходимость вечного поиска в искусстве.

В картине Попкова «Мать и сын» художник написал себя больным, лежащим в кровати под большим одеялом, а мать изобразил стоящей рядом и читающей Библию. Произведение наполнено теплом и уютом, которые художник ощущал, приезжая к матери. Степанида Ивановна была очень набожна, много лет проработала в церкви звонарём - именно молитвой она излечивает сына, водя пальцем по строчкам из Библии и обращаясь одновременно к сыну и к иконе Божьей Матери в красном углу. Виктор Ефимович никогда не был истово религиозным человеком, но всегда с уважением относился к верующим людям. Мотив материнства присутствует в картине двояко - в образах матери и сына и в иконе Богородицы с Иисусом Христом. Это перекличка с вечной темой Богоматери с младенцем - темой жертвенной материнской любви и молитвенного прошения за сына, которому суждено пронести свой крест.

Удивительно, что именно в Германии им была задумана картина «В соборе», изображающая внутреннее убранство русского храма, словно недолгое пребывание за границей всколыхнуло ностальгию по своему, родному, русскому. ...Мы видим туристов, поднявших головы к фрескам удлинённые, почти бесплотные (не до конца прописанные) фигуры людей сами похожи на почти 
стёртые временем фрески и выглядят менее реальными, чем тени изображений, сохранившихся на стенах собора, - точная метафора эфемерности человеческого существования, преходящего и быстротечного, в отличие от многовековых фресок. К этой картине Попков сделал много карандашных и живописных этюдов с древнерусских росписей.

Особняком в творчестве мастера стоит картина «Мне 40 лет» (1972), написанная, вероятно, под влиянием русской иконописи. Глядя на созданный художником образ можно почувствовать, что сорокалетие стало для автора важным рубежом, поводом осмыслить собственную жизнь и то, что он успел сделать к этому сроку. В центре картины - ангел, бесплотное, почти полностью прозрачное существо с огромными распахнутыми крыльями, который держит в руках голову художника, тогда как тело последнего лежит обезглавленным у его ног. Без головы, с изломанными жестами рук, оно выглядит абсолютно беззащитным, но крыло ангела распростёрлось над ним, как защитная броня.

В другой биографичной картине Попкова «Мой день» (1968) можно увидеть, как полностью рушится система координат, и три образа предстают в обводках, наподобие фресковых образов, приобретая символическое измерение.

Другой пример картины на религиозную тему в творчестве Виктора Попкова - полотно «Северная часовня» (1973). Главный герой здесь маленький мальчик, который выполняет также и функцию зрителя. Помещая его фигуру перед открытой дверью в сакральное пространство часовни, художник тем самым фокусирует внимание на «вхождение отрока в храм, в приобщении к духовному».

В первоначальном эскизе картины «Северная часовня» мальчик (мы видим только его голову) стоит в центре церкви рядом с иконостасом, под куполом, расписанным пёстрыми фресками и занимающим большую часть композиции. Преобладает ликующее настроение: празднично пламенеет красками иконостас; купол, разделённый на сектора - небесно-голубой с красными всполохами фигур святых, - кажется лучащимся и напоминает солнце. Художник выбрал такой ракурс, что зритель чувствует себя разглядывающим купол с запрокинутой головой, вплоть до ощущения лёгкого головокружения - понимая что творится в душе у мальчика. В итоговом ва- рианте присутствуют фигуры, изображённые над входом в часовню. Композиция выстроена так, что в них видятся ангелы-хранители, слетевшиеся к входу, чтобы осенить мальчика и всех входящих. Пространство часовни воспринимается вознесённым над землей домом Божьим, красоте которого дивится мальчик, а дверной проём кажется окном с небес на землю.

Знаковой в этой теме стала и другая картина Попкова «Хороший человек была бабка Анисья». Для усиления плоскостного эффекта, более ярко подающего основную группу персонажей, окончательный вариант картины был написан не масляными красками, а темперой. Но сосредоточение на главном, конечно, не умаляло деталей. По мысли художника, именно возможность рассмотреть детали должна была сделать пространство картины более близким, даже родным для зрителя, а также дать ключ к пониманию общего замысла произведения. В заметках художника встречается такая надпись: «Писать «Бабку Анисью» как цветную гравюру и икону...Лица, как в иконах, охра, лепка, пробела». Действительно, эту «иконность» можно прочувствовать, глядя на картину: персонажи, в плаче прижавшиеся друг к другу, напоминают фигуры с икон, силуэт изображенной со спины фигуры в светлом дождевике подобен силуэту ангела, да и в целом мотив оплакивания, прощания абсолютно иконописный, в качестве возможного прообраза невольно вспоминается Успение Богородицы. Это принципиально другой язык - язык метафизических понятий, который для всякого столетия вне времени.

Интересно, что, обращаясь к проблеме духовных истоков искусства 1960-х годов, А.И. Морозов ставил акцент на внутреннем художественном родстве Корина и Попкова: «Любопытно заметить, что становление Попкова происходило не без косвенного влияния П.Д. Корина. Середина 60-х годов - время, на которое приходился пик популярности старого мастера, связанный с выходом к публике цикла его «Руси». Героини картины «Воспоминания. Вдовы» (1966-1968) - первого шедевра зрелого Попкова - непроизвольно перекликались с коринскими персонажами. Они воспринимались как мощный историконациональный тип, которому не было другой аналогии в нашей живописи». В архиве художника была найдена фотография, запечатлевшая Виктора Попкова среди присутствовавших на отпевании Корина в Успенском соборе Новодевичьего 
монастыря. Это подчёркивает неотрывность духовных и художественных традиций, несмотря на все усилия советских властей вымарать наследие прошлого и построить соцреализм на голом месте.

Одним из примеров обращения «суровых» к религиозной проблематике являются произведения Николая Андронова, в которых художник косвенно использовал библейские мотивы и христианскую иконографию. Путём выстраивания тончайших ассоциаций, сложных намёков, использования иконографических принципов он создаёт некое переплетение, перекличку между евангельскими сюжетами и жизнью обычной деревни. Метафорический смысл у Андронова не всегда лежит на поверхности, но, с другой стороны, абсолютно понятен посвящённому зрителю. Так, например, в картине «Ликбез» (1972) обучение грамоте деревенских жителей прочитывается как распространённая в религиозном искусстве новозаветная сцена «Тайной вечери», а в полотне «Семья» (1976) - евангельский сюжет «Рождество».

В «Ликбезе» на подобную аллюзию указывает число участников, благообразный, как бы списанный с икон, облик крестьян, имитация лазоревых побел на одеждах, характерная пластика персонажей. Стоит также обратить внимание на пространство между двумя центральными фигурами, сидящими спиной к зрителю на первом плане: своими чертами оно похоже на кубок - мотив, распространённый в иконописи и служащий напоминанием о евхаристической чаше. Появляется и такая деталь, как изображение собаки в правом нижнем углу. Собака в композициях «Тайной вечери» часто находилась рядом с Иудой, который разными изобразительными приёмами, но всегда обособлен среди учеников, например, цветом одежды, а в тех случаях, когда все ученики изображались с нимбами, его нимб мог быть написан чёрным или вовсе отсутствовать. Всё это может быть отнесено и к фигуре на картине Андронова, сидящей спиной к собаке, её платок, относительно других героев, художник выделил тёмным цветом. Таким образом, через сопоставление с одним из божественных таинств обучение крестьян грамоте воспринимается как процесс их приобщения к миру духовной культуры. Художник передал состояние постижения тайны, превращения незнающих крестьян в число посвящённых.

В картине «Семья» художник внимательно относится к каждой детали картины и выводит из, казалось бы, бытового мотива образ библейского события. Деревенский быт, таким образом, приобретает особое звучание. Мужской персонаж может восприниматься как Иосиф-плотник и как простой крестьянин, а женский образ как Мария или как женщина-крестьянка. Можно увидеть и два источника света: открытую дверь и мистический свет из яслей. Появление ирреального источника можно связать с традиционной иконографией сюжета Рождества.

В деревенской серии Андронова связующим звеном между миром человека и миром природы выступает окно, соединяя мир быта с миром духовного. С другой стороны, оконная рама становится своего рода границей между человеком и необъятной природой. В этом смысле серия окон Андронова становится символом той уединённой, созерцательной, наполненной внутренней работой жизни, которую художник вёл в Ферапонтове.

Есть у Николая Ивановича автопортреты на фоне икон. Их парадокс заключается в том, что трудно назвать другое произведение в нашем искусстве, где с такой очевидностью узнаётся человек поколения 1960-х годов. В «Автопортрете в музее» герой в своём свитере с крестчатым узором, как и на ризах святого, по духу принадлежит той же почве, что создала древний иконный образ.

Образный мир живописи Николая Андронова представал, как правило, в формах исключительно цельных и концентрированных. Можно невооружённым глазом заметить пронизывающие эту цельность пластические, пространственнокомпозиционные и духовные скрепы, наработанные творческим и человеческим опытом мастера. Осмысление мастером пейзажа XIX века, наследия русского авангарда начала XX века, живописи 1920-х годов сочеталось с глубоким интересом к фреске (Дионисий).

Художнику была чужда недооценка нашей духовной традиции, включая и церковное предание и фольклор, и древние архитектурные памятники - храмы, которые он пишет так часто и истово, и память о любимом Дионисии, и иконы, которые он пристально разглядывает как в музее, так и в деревенской избе. Всё это для Андронова - не просто крупицы памяти, но в огромной степени работа души и испытание живой человеческой совести

Как и у других представителей «сурового стиля», живопись Гелия Коржева во многом 
очищается от второстепенных деталей, и его персонажи не принадлежат этому веку. Среда у Коржева условна в той же степени, что пейзаж иконы. И обобщенная человеческая фигура с сотен его картин - портрет народа, через который в его живописи преломляется эпоха.

Главная, самая известная картина в творчестве художника — «Следы войны». Портрет солдата, прямо глядящего на зрителя единственным пронзительно-голубым глазом, с лицом невинным, обтянутым тонкой обожжённой кожей. Увечный, грязный, опалённый огнём и солнцем человек. Если закрыть одну часть лица - мы увидим мёртвого с заострённым носом, другую - живого, сильного человека. Это почти икона - лицо анфас, без эмоций, фона нет реальность, в которой он находится, не уточнена. «Следы войны» - словно бы негатив картины Дюрера. Тот же монохромный фон, только тёмный. Лицо человека иконописно и прекрасно.

Коржев пережил страну, в которой был признан, тяжело воспринял её развал, но и изменился сам, оставив прежде важные и актуальные темы, и освоил новые. Интересно, что, не будучи воцерковлённым человеком, он после смерти родителей обратился к библейским сюжетам. И это только помогло ему в творчестве. Но художник почти не изменил выработанных ещё в молодости приёмов. Мать на картине 1964 года написана почти так же, как мать в «Несении креста» из библейского цикла 1999 года.

Над этим циклом художник работал четверть века - с середины 1980-х годов и до конца жизни. Начиная разрабатывать библейский цикл или даже чуть ранее, Коржев отдаляется от активной общественной деятельности и становится едва ли не отшельником. Обращение мастера к библейской теме стало продолжением его размышлений об основных духовно-нравственных и философских проблемах и было реализовано с удивительной прямотой. В трактовке сюжетов Ветхого и Нового Заветов главным для Коржева - художника-мыслителя, умудрённого богатым жизненным опытом, - стало выстраивание внутренней логики повествования, исходя из этических и нравственных представлений, определяющих поступки человека.

Религиозно-философская проблематика появляется и в произведениях деревенской серии Павла Никонова. Одним из её решений становится воплощение сюжетов Священного писания в бытовых зарисовках, которые через иконографические ассоциации с библейскими сценами теряют прямолинейность трактовки и приобретают дополнительный смысл. Никонов обобщает фигуры до состояния знаков и доводит пейзаж до состояния условных иконописных горок. Такой перенос евангельских событий в конкретное измерение не был чем-то уникальным: по словам Никонова, когда он задумал серию картин на библейскую тему, он вспоминал о творчестве нидерландского мастера Питера Брейгеля Старшего.

Свою духовную родину Пётр Оссовский обрёл на земле древней Псковщины с её первозданной красотой и суровым былинным величием, удивительной природой и мужественными людьми, что нашло отражение во многих его тематических картинах, приближавшихся к иконным образам. В портретных образах: «Подвижник», «Псковитянка», «Егерь Михаил», «Василиса», «Сибирский старожил», «Мать и отец» он подмечал черты, свидетельствующие о моральной чистоте русского человека, цельности личности, о служении своей земле и вере в своё предназначение. Особое значение имеет серия автопортретов, которую мастер писал на протяжении всей жизни. Наиболее поздний из них - «Автопортрет. Белый квадрат холста», в нём художник заключил серьёзные раздумья о судьбе творческой личности в обществе, её роли и значении.

Земля древнего Пскова, которую Оссовский называет своей духовной родиной, стала для художника источником образов, отображающих не только национальное своеобразие русской провинции середины прошлого столетия, её особую патриархальную атмосферу и самобытность, но и оказывающихся как бы астральными - вне времени и определённого пространства.

Герои произведений Виктора Иванова аскетичны и строги, картины монументальны, в них очевидно влияние иконописи, которой увлекались многие художники «сурового стиля», как и раньше авангардисты (не зря Иванов учился в мастерской бубнововалетовца Александра Осмеркина).

Одна из лучших картин Иванова - «Семья. 1945 год» (1957-1964), рассказывающая о первых днях мирной жизни после победы над фашизмом. Его холст - характерный образец «сурового стиля», изображает торжественную крестьянскую трапезу, где за внешней сдержанностью эмоций скрываются глубокая нежность и радость вновь обретённой целостности. 
В своих последних работах он остаётся верен крестьянской теме и так же безразличен к временным рамкам. Его Косцы (1991) в белых рубахах могли быть написаны и в 1970-е, да и убирающие стога крестьянки с иконописными лицами в Рязанских полях (2005) словно застыли в вечности.

Пейзажи Иванова представляют мир таинственный и беспредельный, природа в них становится молельным образом. Одним из часто повторяющихся мотивов его панорамных пейзажей - изображение на заднем плане храма, стоящего на высоком берегу. Возвышенность эта, как основание для храма, как бы является твёрдым основанием веры.

Между картинами Виктора Иванова существует внутренняя, духовная связь, в них он отражает устойчивость, весомость жизненных явлений. Отсюда композиции, сила цвета, наполненность всей формы. Произведения художника посвящены людям современной деревни, но он не является её бытописателем. Деревенская жизнь, труд людей - это тема, пронизанная единым замыслом, через которую Иванов несёт зрителю свои взгляды на мир, высказывает идеи времени, утверждает свои идеалы.

Многие критики причисляют Дмитрия Жилинского к художникам «сурового стиля», однако сам мастер считал, что он «только жил одновременно с ними». Тем не менее, многое и роднило художника с коллегами по направлению. В своём творчестве Жилинский обратился к наследию древнерусской иконописи, а также итальянского и Северного Возрождения. За каждым явлением, героем или предметом в его картинах скрывается целая история, полная метафорических уподоблений, символов и аллегорий. Произведениям этого мастера свойственна насыщенность символами, в его полотнах нет случайных деталей.

Один из самых проникновенных в творчестве Жилинского - образ матери, Анастасии Фёдоровны. Наиболее ярко он представлен в картине «Под старой яблоней» (1969), посвящённой трагической истории семьи художника. В качестве основы Жилинский использовал доску, подготовив её по образцу иконы, в ковчеге - углублённом среднем поле на лицевой стороне доски изобразил свою мать и детей, а на полях поместил фигуры отца, расстрелянного в 1937 году, и брата, погибшего на фронте в 1944 году. Сопоставление плодоносящего дерева и женщины в окружении внуков становится метафорой несокрушимой жизненной силы. Картина в своей выкрашенной белой краской широкой плоской раме с размещёнными на ней двумя изображениями вызывает в памяти древнерусские иконы с клеймами на полях. Техника, в которой выполнено произведение (темперными красками по левкасу), также идёт из древнерусской иконописи.

Чрезвычайно выразителен офорт Владими-

ра Дайчмана «Сикстинская мадонна», выполненный в духе «сурового стиля». Вертикальный формат листа подчёркивает узкое пространство бункера, где в варварском небрежении складированы холсты. Ступени пыльной лестницы ведут вверх. Там, в проёме распахнутой двери, - красноармеец с автоматом. Лучи солнечного света выхватывают из темноты лик Мадонны с ребёнком. Динамичность сцене придают разворот фигуры солдата, контраст яркого света, льющегося с улицы, и темноты помещения, особый характер штриха. Эта картина - как символ постоянной борьбы советского варварства и неприятия традиций против вечной красоты иконных образов и великих живописных произведений, ставших иконографичными.

К сожалению, у «сурового стиля», возникшего в пику бесконечным изображениям ликования советских праздников и парадных портретов вождей, были свои слабые стороны. Многие его адепты со временем стали заложниками собственной художественной программы: поиск лаконичной простоты часто приводил к известной выхолощенности и схематизации образов, а стремление к монументальности иногда оборачивалось равнодушием к деталям и гиперболизацией изображаемого. Парадоксально, но с течением времени мастера этого стиля, изначально ставившие своей целью отражение правды жизни, всё чаще стали создавать в своих работах своеобразную трудовую мифологию, по сути, впадая в то же мифотворчество, против которого некогда боролись. Обретённая новизна, свежий взгляд на жизнь со временем вырождались в клише.

Однако лучшие работы этого направления, в которых особенно ярко прослеживается связь с иконописью, являются замечательными примерами творческой свободы. В них художники не оглядывались на идеологические указания, для многих из них таким творческим маяком была русская икона с её чистыми красками, лаконизмом, правдой. Именно этими чертами представители «сурового стиля» наделяли картины, которые стали явлением советской эпохи 1960-1970-х и пробивались 
к зрителю, как свет иконы пробивается сквозь стены к верующему человеку.

Образы в этих работах не индивидуализированы, а, скорее, обобщены, однако пониманию душевного состояния персонажей это никак не мешает, может быть, даже наоборот - делает его более чистым, отрешённым от конкретных примет реальности, и потому более глубоким. Стремление художников отобразить неотобразимое закономерно становится в этих картинах сродни задачам, которые веками стояли перед русскими иконописцами.

Художники «сурового стиля» через метафорический живописный язык возвращали оторванному от корней советскому народу исконные традиции русской жизни, в которой икона всегда проходила центральной осью, была фундаментом, скрепляющим основы духовной жизни.

Но схожесть с иконой была не только в изобразительных, духовных и философских смыслах, но проявлялась ещё и в социальной роли больших полотен живописцев «сурового стиля», стано- вившихся своего рода образцом для подражания. Монументальность, плакатность, крупноформатность, лаконизм и экспрессия - всё это придавало полотнам остроактуальное и, вместе с тем, эпическое, высоко гражданственное звучание. Картины оказали, безусловно, высокое влияние на кинематограф и живопись последующих десятилетий, ставя новые вопросы нравственного и этического толка.

Будучи русскими по рождению, художники «сурового стиля» вышли, возможно, сами того не ведая, на уровень больших национальных художественных обобщений, сделанных ими на материале сугубо русском, исходя из собственного опыта и знания жизни своего народа.

«Суровый стиль» - явление, которому так безапелляционно присваивали статус чего-то эпизодического, даже мимолётного, оказалось в разных вариантах совместимым с актуальными во все времена философскими и религиозными постулатами, национальной идеей, влечением к вечности.

\section{БИБЛИОГРАФИЯ}

1. Алексеева Т.П. Образы народа и судьбы индивидуальности в живописи сурового стиля [Текст] / Т.П. Алексеева, Н.В.Виницкая // Культурное наследие Сибири.- 2017.- Т. 3. - № 21.- С. 40-45.

2. Библия глазами соцреалиста. Гелий Коржев [Текст] $=$ The Bible througt the eyes of a socialist realist. Gely Korzhev: каталог выставки, 12 декабря 2012-27 мая 2013 / [текст К. Карпова]. - Москва: Сканрус, 2012.127 с.: ил., портр., цв. ил.

3. Бобриков А.А. Суровый стиль: мобилизация и культурная революция [Электронный ресурс] / А.А. Бобриков // Художественный журнал.2003. - № 51-52. - С. 29-33. - Режим доступа: http:// moscowartmagazine.com/issue/57/article/1137 (дата обращения: 31.12.2020).

4. Бондаренко, Л.К. Тема деревни в творчестве советских живописцев 1960-1970-х годов: дис. ... кандидата искусствоведения: 17.00.04 [Текст] / Бондаренко Людмила Константиновна; [Место защиты: Моск. гос. акад. Худож. ин-т им. В.И. Сурикова].- Москва, 2005. - 193 c

5. Бурганова М.А. Суровый стиль: прямая речь [Текст] / М.А. Бурганова // Дом Бурганова. Пространство культуры.- 2008. - № 1.- С. 8-33.
6. Буткевич Д. С уклоном в суровый стиль [Текст] / Д. Буткевич // Независимая газета.- 2006.- 27 января.- С. 3.

7. Дехтярь А.А. Павел Никонов [Текст] / А. Дехтярь.Ленинград: Художник РСФСР, 1981.- 69 с.: ил.

8. Зайцев Е. В. Гелий Михайлович Коржев: [Альбом]: К 75-летию со дня рождения [Текст] / Евгений Зайцев; [Рос. акад. художеств. Науч.-исслед. ин-т теории и истории изобраз. искусств]. - Москва: Пассим, 2000.- 111 с.

9. Виктор Попков [Текст] / [текст: Козорезенко П. П. мл.; фот.: Кубарев В. Г.].- Москва: [б. и.], 2012.- 457, [6] с.: ил., портр., цв. ил.

10. Волошина И. Виктор Попков: Художник на вдовьей земле [Текст] / И. Волошина // Фома.- 2015.№ 12.- С. 62-71.: ил.

11. Время перемен: искусство 1960-1985 в Советском Союзе: [каталог] [Текст] / Государственный Русский музей. - Санкт-Петербург: Palace Editions, 2006. - 415 с.: ил., цв. ил.

12. Matthew Cullerne Bown. Art under Stalin.- Oxford, Phaidon Press, 1991.

13. Realismi socialisti. Grande pittura sovietica 1920 1970. - Milano, Skira, 2011. 